\title{
EVALUATING CRANIOCERVICAL POSTURE BY USING A PHOTOGRAPHIC POSTURAL ANALYSIS İN ADOLESCENTS WITH DIFFERENT MALOCCLUSIONS
}

\author{
Refik Hilmi BARIŞ ${ }^{1}$, Nevin A. GÜZEL ${ }^{1}$, M.Okan AKÇAM ${ }^{2}$, Nihan KAFA ${ }^{1}$, Emre AYYILDIZ ${ }^{2}$ \\ ${ }^{1}$ Gazi University, Faculty of Health Sciences, Department of Physiotherapy and Rehabilitation, Ankara, Turkey. \\ Ohttps://orcid.org/ 0000-0002-8118-597X, Dhttps://orcid.org/ 0000-0003-0467-7310, Ohttps://orcid.org/ 0000- \\ 0003-0467-7310, @ittps://orcid.org/ 0000-0003-2878-4778
}

${ }^{2}$ Ankara University, Faculty of Dentistry, Department of Orthodontics, Ankara, Turkey.

(D) https://orcid.org/ 0000-0001-9212-3670

\section{ABSTRACT}

The aim of the present study was to evaluate the craniocervical posture in adolescents with different malocclusions using a practical photographic posture analysis method. Thirty-two adolescents (10-15 years) were recruited. Angle's Classification was used in malocclusion classification according to the relationship between the upper and the lower dental arch. The subjects were divided into three groups as Angle Class I (10 subjects), Angle Class II (12 subjects) and Angle Class III (10 subjects). Craniocervical postural assessments were conducted using a 'photographic posture analysis' method. Photographs of subjects' habitual standing posture were taken in the sagittal plane from 1.5 meters away and analyzed based on three substantial postural angles (sagittal head angle, cervical angle and shoulder angle). The data were analyzed using The Shapiro-Wilk test and Kruskal Wallis test. No statistically significant differences were detected between three groups ( $>>0.05)$, however, sagittal head and shoulder angles were signifacantly lower in the Class II and III groups when compared to Class I. According to our results, by using the photographic method, no difference was detected in craniocervical posture in adolescents with different malocclusions.

Keywords: Malocclusion, Posture, Craniocervical, Adolescents

\section{FARKLI TIPTE MALOKLÜZYONA SAHİP ADÖLESAN BİREYLERDE FOTOGRAFIK KRANIOSERVIKKAL POSTÜRAL DEĞERLENDİRME}

\begin{abstract}
ÖZ
$\mathrm{Bu}$ çalışmanın amacı, farklı tipte maloklüzyonlu adölesan bireylerin kranioservikal postürlerini, pratik bir yöntem olan fotografik analiz metodu kullanılarak değerlendirmektir. Otuz iki adölesan birey (10- 15 yaş) çalışmaya dahil edilmiş̧ir. Katılımcıların maloklüzyon tiplerinin belirlenmesinde üst ve alt dental ark arasındaki ilişkiye göre Angle Sınıflandırması kullanılmıştır. Katılımcılar Angle Sınıf I (10 kişi), Angle Sınıf II (12 kişi) ve Angle Sınıf III (10 kişi) olmak üzere üç sınıfa ayrılmıştır. Katılımcıların kranioservikal postür değerlendirmesinde fotografik postür analiz yöntemi kullanılmıştır. Katılımcıların alıştıkları postürde ayakta duruşlarının fotoğrafları 1.5 metre uzaklıktan sagittal düzlemde çekilmiş olup, çekilen fotoğraflar üzerinden üç postüral açı (sagittal baş açısı, servikal açı, omuz açısı) değerlendirilmiştir. Elde edilen veriler The Shapiro-Wilk ve Kruskal Wallis testleri kullanılarak analiz edilmiştir. Üç sınıf arasında istatistiksel olarak anlamlı bir fark saptanamazken ( $p>0,05)$, sagittal baş ve omuz açılarının değerleri, Sınıf II ve Sınıf III 'de Sınıf I’e göre daha düşük olduğu tespit edilmiştir. Fotografik postüral analiz yöntemi kullanılarak elde edilen sonuçlara göre, farklı tipte maloklüzyonlara sahip adölesan bireylerin kranioservikal postüral değerlendirmelerinde farklılık tespit edilememiştir.
\end{abstract}

Anahtar Kelimeler: Maloklüzyon, Fotografik Postüral Analiz, Kranioservikal, Adölesan

İletişim/Correspondence

Refik Hilmi BARIŞ

Gazi University, Faculty of Health Sciences,

Department of Physiotherapy and Rehabilitation, Ankara, Turkey.
E-posta: r.hilmibaris@gmail.com

Geliş tarihi/Received: 21.07.2021

Kabul tarihi/Accepted:07.08.2021

DOI: $10.52881 /$ gsbdergi.973515 


\section{INTRODUCTION}

'Malocclusion' is defined as a disorder that occurs with the loss of normal occlusal relationship between the teeth when the upper and lower jaws are closed. In orthodontics, malocclusion refers to not having only dental disorders, but also presenting skeletal incompatibility between the jaws $(1,2)$. The main classification of malocclusions was performed by Dr. Edward H. Angle in 1889. The relationship between the upper and the lower dental arch was classified in three classes according to Angle's Classification. Angle Class I occurs when the mesiobuccal cusp of the upper first molar occludes with the buccal groove of the lower first molar. Angle Class II occurs when the upper first molar occludes anterior to the lower first molar. Angle Class III occurs when the upper first molar occludes posterior to the lower first molar $(1,3)$.

'Posture' refers to position of the body segments related to each other. The American Academy of Orthopaedic Surgeons (AAOS) defines good posture as a state of muscular and skeletal balance (4). This balance protects the structures of the body against injury or progressive deformity by allowing optimum position of the thoracic and abdominal organs. The good posture exerts minimal amount of stress on the body and helps the muscles to work with minimal energy consumption in the most efficent position $(4,5)$. In poor posture, changes in the alignment of the body parts are occurred and this leads to malaligments in the body structures and an increase in the amount of energy consumed. Deviations from the ideal posture may increase stress on the tissues around the spine, causing lower back and neck pain (6).
Nowadays, the incidence of postural problems is increasing in both adults and adolescents due to advanced technology which keeps people in certain positions for prolonged hours. Especially in school-age children, it is stated that the rapid changes in growth, the use of an asymmetric, heavy backpack and the effects of non-ergonomic school furniture and spending too much time on technological devices may cause postural problems $(6,7)$. Musculoskeletal pain is one of the responsible symptoms regarding to postural disorders in children and adolescents. Especially, shoulder and neck regions are important areas for musculoskeletal problems and forward head posture and shoulder protraction are stated as the most common postural problems occur in these regions (6-8).

In the presence of postural problems in head posture, the muscles may not work correctly and simultaneously. This may adversely affectted craniofacial morphology, especially in childhood, as the growth of the structures in the cranio-dento-facial region can be influenced by environmental factors as well as genetic factors. Consequently, the balance between joints, myofascial structures and dental occlusion may be disrupted. Deviation from the natural position of the head causes tension on the soft tissues of the head and neck region; thus, it causes different adoptions in the skeletal structure. Therefore, incorrect posture can lead to skeletal and dental morphological problems such as malocclusions (9-11). In additon, the treatment of malocclusions is mostly started in childhood and adolescence (12). It was recommended that muscle imbalances directly related to craniofacial development 
should be considered in the treatment of malocclusions, especially at the young age, in terms of timing, planning and determining the mechanics of the treatment

Many authors reported links between individuals with dento-facial deformities and individuals with forward head posture and increased cervical lordosis curve $(1,10$, 14, 15). However, the results of these studies are still controversial. Additionally, radiography was used in the majority of studies. Even though, the radiographical examination is the golden standard for determining postural problems, participants may be exposed to unneseccary radiation in this method. In addition, radiography can be time-consuming and expensive. Thus, the present study aimed to contribute to the literature using a practical and radition-free method for postural assessment. Therefore, the objective of the present study was to determine possible craniocervical postural differences in individuals with different malocclusions using a photographic posture analysis method.

\section{MATERIALS AND METHODS}

The study included 32 adolescents (mean age: $12.47 \pm 1.74$ years; mean Body Mass Index (BMI): $18.37 \pm 3.44 \mathrm{~kg} / \mathrm{m}^{2}$ ). Subjects were randomly selected among patients who applied to the Ankara University, Faculty of Dental Medicine, Department of Orthodontics. Postural measurements were performed in a physiotherapy and rehabilitation clinic of Gazi University, Faculty of Health Sciences, Department of Physiotherapy. The inclusion criteria were being adolescent, having an orthodontic craniofacial anomaly and having normal vertical face dimension values. Participants who had a congenital missing tooth, genetic or congenital craniofacial deformities, temporomandibular joint disorders, a history of upper body surgery or current pain limiting activities, scoliosis and systemic diseases were excluded from the study. The subjects were divided into three groups according to cephalometric measurements as Angle Class I (10 subjects (3 males/ 7 females)), Angle Class II (12 subjects (7 males/ 5 females)) and Angle Class III (10 subjects ( 5 males/5 females)). Malocclusions are classified based on the positioning of the upper and lower molar teeth. Angle Class I group means that the molar position is normal, but there are minimum crowding on the anterior zone. Angle Class II group is described that the first maxillary molar is anteriorly positioned relative to mandibular first molar. When the maxillary first molar is positioned posteriorly to the mandibular first molar, it is called Angle Class III. Therefore, Angle Class I group was used as the control group (16).

All participants were informed about the research procedures before giving informed consent. A signed informed consent was obtained from all the participants' families. The study was approved by the research ethics committee of Gazi University (file number: 2019-007) and was conducted in a manner consistent with the institutional ethical requirements for human experimentation in accordance with the Declaration of Helsinki. 
For postural analysis, sagittal head angle, cervical angle and shoulder angle were used. These angles were chosen because they were found to be reliable and have been commonly used in other studies and clinical researches for cranio-cervical posture measurements $(8,17,18)$ (Figure 1).

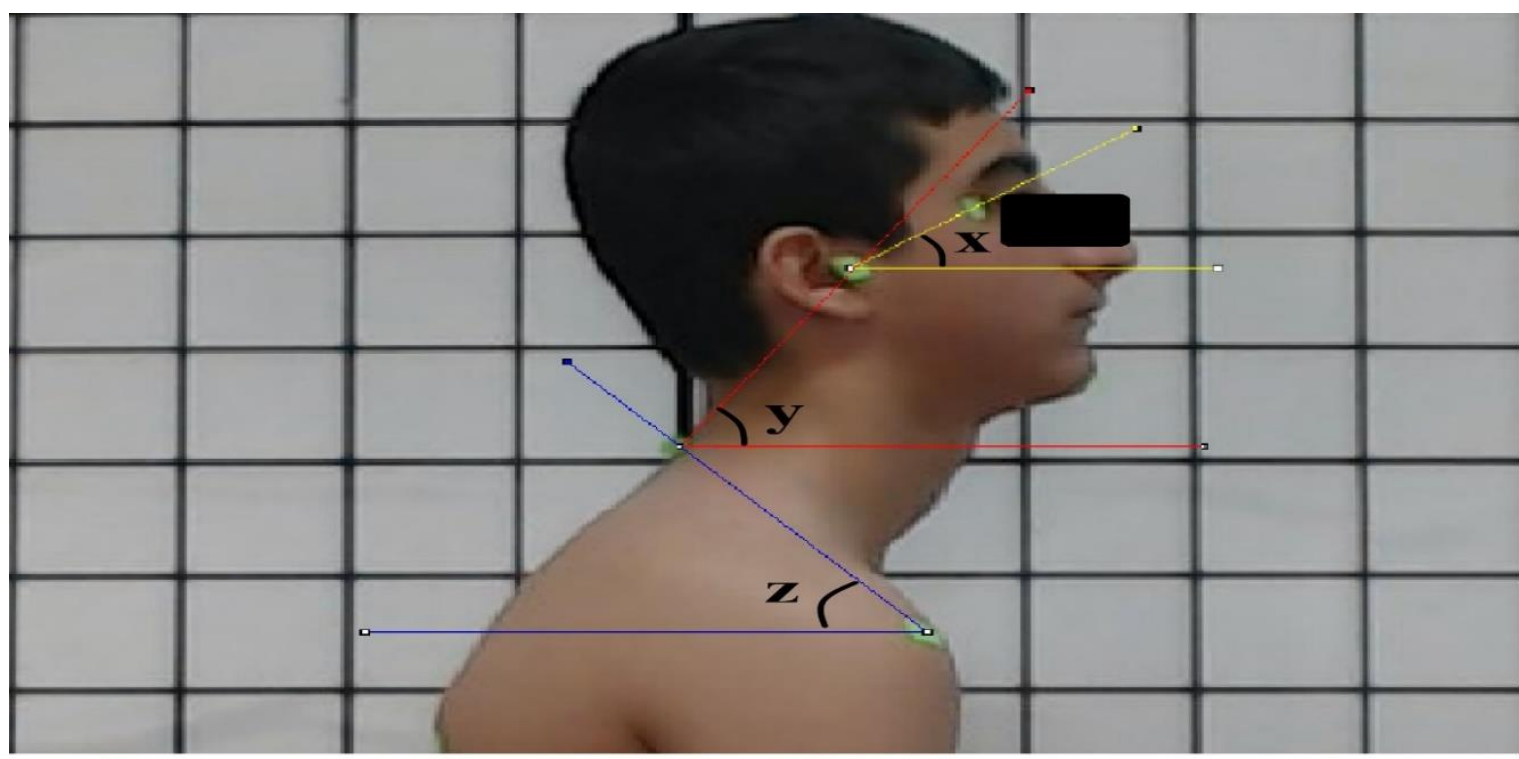

Figure 1: Angles used for postural assessment; x: Sagittal head angle, y: Cervical angle, z: Shoulder angle

Sagittal head angle: The angle between a horizontal line through the tragus of the ear and a line drawn through the tragus of ear to the external canthus of the eye. This angle indicates the position of the head relative to the neck.

Cervical Angle: The angle between a horizontal line through the spinous process of $7^{\text {th }}$ cervical vertebrae $(\mathrm{C} 7)$ and a line drawn from $\mathrm{C} 7$ to the tragus. This angle is used to define the forward head position. Smaller angles indicate more forward head posture.

Shoulder angle: The angle between a horizontal line through the midpoint of the humerus and a line drawn from the midpoint of the humerus to spinous process of $\mathrm{C} 7$. It defines retraction or protraction of the shoulders. All postural measurements and the photographic analysis were performed by the same researcher who was experienced in the assessment of postural alignment. Analyzes of photos were subsequently performed using ImageJ computer software.

\section{Statistical Analysis}

Statistical analysis of the study was performed using the Statistical Package for Social Sciences (SPSS; version 22.0; SPSS Inc., Chicago, IL, USA) and the statistical significance level was defined as $\mathrm{p}<0.05$.

The Shapiro-Wilk test was used to assess normality. For the descriptive statistics, the median and interquartile ranges between quarters were calculated. Differences between groups were analyzed using Kruskal Wallis test. 


\section{RESULTS}

A total of 32 participants (17 females and 15 males) aged 10 to 15 years were recruited in the study. Characteristics of subjects were shown in Table 1.
No statistically significant difference was detected between groups for age, BMI and gender $(\mathrm{p}>0.05)$.

Table 1. Class characterization regarding age and BMI

\begin{tabular}{|l|c|c|c|c|}
\hline \multirow{4}{*}{ Variables } & Class 1 & Class 2 & Class 3 & \multirow{2}{*}{ p } \\
\cline { 2 - 4 } & $\begin{array}{c}\text { Median (IQR) } \\
\mathbf{( 2 5 t h - 7 5 t h} \\
\text { percentile) }\end{array}$ & $\begin{array}{c}\text { Median (IQR) } \\
\mathbf{( 2 5 t h - 7 5 t h} \\
\text { percentile) }\end{array}$ & $\begin{array}{c}\text { Median (IQR) } \\
\mathbf{( 2 5 t h - 7 5 t h} \\
\text { percentile) }\end{array}$ & \\
\hline Age (years) & 12.50 & 12.00 & 13.00 & 0.997 \\
& $(10.75-14.25)$ & $(11.00-14.00)$ & $(10.75-14.00)$ & \\
\hline BMI $\left(\mathbf{k g} / \mathbf{m}^{\mathbf{2}}\right)$ & 18.40 & 16.65 & 18.60 & 0.652 \\
& $(16.32-20.25)$ & $(14.85-19.77)$ & $(15.65-22.62)$ & \\
\hline
\end{tabular}

IQR: The interquartile range. BMI: Body mass index. Statistical significance ( $\mathrm{p}<0.05)$.

Comparisons of postural variables between the study groups were given in Table 2 . No statistically significant differences were found between the groups for no variables $(\mathrm{p}>0.05)$.
However, sagittal head and shoulder angles were significantly lower in the Class II and III groups compared to Class I group. Cervical angle showed the highest value in Angle Class II group.

Table 2. Comparision of postural variables between three classes

\begin{tabular}{|c|c|c|c|}
\hline Variables & Class & $\begin{array}{c}\text { Median (IQR) } \\
\text { (25th-75th percentile) }\end{array}$ & $\mathbf{p}$ \\
\hline \multirow[t]{3}{*}{ Sagittal Head Angle (Degree) } & Class 1 & $\begin{array}{c}24.76 \\
(16.26-26.04)\end{array}$ & \multirow[t]{3}{*}{0.380} \\
\hline & Class 2 & $\begin{array}{c}18.55 \\
(15.12-24.83)\end{array}$ & \\
\hline & Class 3 & $\begin{array}{c}18.26 \\
(17.27-19.87) \\
\end{array}$ & \\
\hline \multirow{3}{*}{$\begin{array}{l}\text { Cervical Angle } \\
\text { (Degree) }\end{array}$} & Class 1 & $\begin{array}{c}49.58 \\
(48.71-56.31)\end{array}$ & \multirow[t]{3}{*}{0.193} \\
\hline & Class 2 & $\begin{array}{c}54.45 \\
(46.60-57.50) \\
\end{array}$ & \\
\hline & Class 3 & $\begin{array}{c}47.62 \\
(46.03-51.06) \\
\end{array}$ & \\
\hline \multirow{3}{*}{$\begin{array}{l}\text { Shoulder angle } \\
\text { (Degree) }\end{array}$} & Class 1 & $\begin{array}{c}44.01 \\
(28.18-5.30)\end{array}$ & \multirow[t]{3}{*}{0.934} \\
\hline & Class 2 & $\begin{array}{c}40.46 \\
(33.80-44.21)\end{array}$ & \\
\hline & Class 3 & $\begin{array}{c}34.70 \\
(31.68-50.19)\end{array}$ & \\
\hline
\end{tabular}

IQR: The interquartile range. Statistical significance $(\mathrm{p}<0.05)$. 


\section{DISCUSSION}

The main objective of this study was to determine whether individuals with different malocclusions had craniocervical postural differences using a photographic posture analysis method. The results indicated that sagittal head and shoulder angles were lower in the Angle Class II and III groups when compared to Class I group. However, the differences between three groups did not reach to a statistically significant level.

The effect of posture on malocclusion is controversial in the literature. This may be related to determining the postural status by using different methods. For example, D'Attilio $M$ et al. evaluated the cervical posture in Class I, II and III occlusions by using cephalograms. In their study, cervical spine was analyzed by dividing into three segments as upper, middle, lower. They reported that the lower cervical spine in Class III was significantly straighter than the other classess and children in skeletal Class II had more head extension in the middle segment of the spinal column (19). In another study, Lippold et al. examined the sagittal profile of the spine in adults with Class II and Class III malocclusions using rastersterography. While they observed increased thoracic inclination and the jaw position in Class II, smaller thoracic angles were detected in Class III (20). In contrast, Sinko et al. compared body postures with video rastersterography in subjects skeletal Class II and Class III, and found that the apex of thoracic kyphosis was more cranial in subjects Class III than in subjects Class II (21). In addition to this, Nobili et al. analyzed this relationship by means of posturography and concluded that subjects with Class II malocclusion exhibited an anteriorly displaced body posture, whereas subjects with Class III malocclusion exhibited a posteriorly displaced body posture (15). In different study with a large population, there no correlation was determined between posture and skeletal occlusions (22). Since the present study used the different method and variables in previous reports, comparisions across studies are difficult. Although using different analysing methods, most of the studies in the literature reported that subjects in Class II had a significantly higher cervical lordosis and thoracic angles compared to subjects in Class I and Class III (1, 23). The present results, especially regarding to Class II, are in agreement with literature.

Decreases in the craniocervical angles indicate an increase in forward-head position, cervical lordosis and kyphotic posture. According to the results of the present study, there were differences in the angles showing postural alignment between three classes. In Class II and Class III individuals, decreased sagittal head, cervical and shoulder angles were observed. The results of the present research tend to follow most of the similar studies in the literature. The fact that the difference was not detected statistically may be related to number of subjects in each class. Additionally, previous researchers observed that, morphological development of the upper segments of the spine is linked to facial development (19). The participants (10 to 15 years old) in the present study were selected from adolescents whose body growth is still continuing. Therefore, especially in younger participants, changes 
in the postural angles may be observed in subsequent measurements.

In the present study, a photographic method was used for postural assessment. This method is simple, cost effective and easy to use. Therefore, it is largely accessible for many researchers. Due to all these positive properties, the photographic method could be useful tool for posture evaluations in occlusal problems. It has been reported in previous studies that this method is a valid and reliable assessment method in adolescents (5). In similar studies which investigating the relationship between malocclusion and posture in the literature, the most commonly used methods included radiography and rasterstereography. The photographic method may be more widely implemented in the clinical postural assessments, however the criteria validitation by using golden standard should be performed in future studies.

To best to our knowledge, Gadotti et al. (16), Deda et al. (24) and Iacob et al. (25) used photographic postural assesment in these subjects group previously. Gadotti et al. (16) and Deda et al. (24) determined anteriorization of the head in Class II individuals compared to Class I and Class III individuals. However, no difference was detected between three classes in the present study. This may be related to the methods used in studies. For evaluating the head posture Gadotti et al. and Deda et al. used a single angle which was different to the present study. However, in the literature, the angles used in the present study are mostly recommended ones (18, $26,27)$. One other study performed by Iacob et al (25) evaluated frontal and lateral angles in malocclusions. Even if they detected a difference in frontal exam, they reported no statistically differences between groups in the lateral exam as in the present study. However, contrary to the our study, Iacob at al. did not evaluate Class II and Class III participants separately.

In the present study, the major limitation is the small sample size. The literature review shows that the number of participants included in similar previous studies varies between 20 and $120(16,19,28,29)$. The initial participant goal in the present study was to reach a higher numbers. Unfortunately, more participants cannot be employed due to current conditions related to Covid-19 pandemic. Therefore, this study was considered a preliminary study of investigating relationship between posture and malocclusions using photographic method. Further studies with larger participants using the photogaphic method may present different results. Additionally, investigating whether there are differences in the activation of the muscles in the head and neck area, in individuals with skeletal malocclusion should be further investigated by using objective methods such as ultrasonography and electromyography.

\section{CONCLUSION}

In the present study, using the photographic postural assessment method, no difference was detected in craniocervical posture in adolescents with different classes of malocclusion.

\section{Competing interests}

The authors declare that they have no competing interests 


\section{REFERENCES}

1. Michelotti A, Buonocore G, Manzo P, Pellegrino G, Farella M. Dental occlusion and posture: an overview. Prog Orthod. 2011;12 (1): 53-58.

2. Hassan R, Rahimah A. Occlusion, malocclusion and method of measurements-an overview. Arch Orofac Sci. 2007; 2 :3-9.

3. Gravely J, Johnson D. Angle's classification of malocclusion: an assessment of reliability. $\mathrm{Br} \mathrm{J}$ Orthod. 1974; 1(3): 79-86.

4. American Academy of Orthopedic Surgeons. Posture and its relationship to orthopaedic disabilities. A report of the posture committee. AAOS; Evanston, Illinois. 1947.

5. Hazar Z, Karabicak GO, Tiftikci U. Reliability of photographic posture analysis of adolescents. J Phys Ther Sci. 2015; 27 (10): 3123-3126.

6. Paušić J, Pedišić Ž, Dizdar D. Reliability of a photographic method for assessing standing posture of elementary school students. J Manip Physiol Ther. 2010; 33 (6): 425-431.

7. Straker LM, Smith AJ, Bear N, O'Sullivan PB, de Klerk NH. Neck/shoulder pain, habitual spinal posture and computer use in adolescents: the importance of gender. Ergonomics. 2011; 54 (6): 539-546.

8. Ruivo RM, Pezarat-Correia P, Carita AI. Intrarater and interrater reliability of photographic measurement of upper-body standing posture of adolescents. J Manip Physiol Ther. 2015; 38 (1): 74-80.

9. Lippold C, Danesh G, Hoppe G, Drerup B, Hackenberg L. Sagittal spinal posture in relation to craniofacial morphology. Angle Orthod. 2006;76 (4): 625-631.

10. Pruneda JFM. Dental malocclusion and its relationship with body posture: a new research challenge in stomatology. Bol Med Hosp Infant Mex. 2013; 70 (5): 341-343.

11. Solow B, Kreiborg S. Soft-tissue stretching: a possible control factor in craniofacial morphogenesis. Eur J Oral Sci. 1977; 85 (6): 505-507.

12. Batista KB, Thiruvenkatachari B, Harrison JE, D O'Brien K. Orthodontic treatment for prominent upper front teeth (Class II malocclusion) in children and adolescents. Cochrane Database Syst Rev. 2018; 13 (3): CD003452-CD003452.

13. Pepicelli A, Woods M, Briggs C. The mandibular muscles and their importance in orthodontics: a contemporary review. Am J Orthod Dentofacial Orthop. 2005; 128 (6): 774780.

14. Manfredini D, Castroflorio T, Perinetti G, Guarda-Nardini L. Dental occlusion, body posture and temporomandibular disorders: where we are now and where we are heading for. J Oral Rehabil. 2012; 39 (6): 463-471.

15. Nobili A, Adversi R. Relationship between posture and occlusion: a clinical and experimental investigation. Cranio ${ }^{\circledR} .1996 ; 14$ (4): 274-285.

16. Gadotti I, Berzin F, Biasotto-Gonzalez D. Preliminary rapport on head posture and muscle activity in subjects with class I and II. J Oral Rehabil. 2005; 32 (11): 794-799.

17. Van Niekerk SM, Louw Q, Vaughan C, Grimmer-Somers K, Schreve K.

Photographic measurement of upper-body sitting posture of high school students: a reliability and validity study. BMC Musculoskelet Disord. 2008; 9(1): 113.

18. Armijo-Olivo S, Rappoport K, Fuentes J, Gadotti IC, Major PW, Warren S, et al. Head and cervical posture in patients with temporomandibular disorders. J Orofac Pain. 2011; 25(3):199-209.

19. D'Attilio M, Caputi S, Epifania E, Festa F, Tecco S. Evaluation of cervical posture of children in skeletal class I, II, and III. Cranio ${ }^{\circledR}$. 2005; 23 (3): 219-228.

20. Lippold C, Danesh G, Schilgen M, Drerup B, Hackenberg L. Relationship between thoracic, lordotic, and pelvic inclination and craniofacial morphology in adults. Angle Orthod. 2006; 76 (5): 779-785.

21. Sinko K, Grohs J-G, Millesi-Schobel G, Watzinger F, Turhani D, Undt G, et al. Dysgnathia, orthognathic surgery and spinal posture. Int J Oral Maxillofac Surg. 2006; 35 (4): 312-317.

22. Perillo L, Signoriello G, Ferro F, Baccetti T, Masucci C, Apicella D, et al. Dental occlusion and body posture in growing subjects. A population-based study in 12-year-old Italian adolescents. Int Dent SA. 2008; 10 (6): 46-52.

23. Šidlauskienè M, Smailienè D, Lopatienė K, Čekanauskas E, Pribuišienè R, Šidlauskas M. Relationships between malocclusion, body posture, and nasopharyngeal pathology in pre- 
orthodontic children. Med Sci Mon Int Med J Exp Clin Res. 2015; 21: 1765.

24. Deda MRdC, Mello-Filho FVd, Xavier SP, Trawitzki LVV. Head posture in the presence of class II and class III dentofacial deformities. Rev CEFAC. 2012; 14 (2): 274-80.

25. Iacob SM, Chisnoiu AM, Lascu LM, Berar AM, Studnicska D, Fluerasu MI. Is PostureScreen ${ }^{\circledR}$ Mobile app an accurate tool for dentists to evaluate the correlation between malocclusion and posture? Cranio ${ }^{\circledR}$. 2020; 38 (4): 233-239.

26. Edmondston SJ, Chan HY, Ngai GCW, Warren MLR, Williams JM, Glennon S, et al. Postural neck pain: an investigation of habitual sitting posture, perception of 'good'posture and cervicothoracic kinaesthesia. Man Ther. 2007;12 (4): 363-371.

27. Raine S, Twomey L. Posture of the head, shoulders and thoracic spine in comfortable erect standing. Aust J Physiother. 1994; 40 (1): 25-28.

28. Liu Y, Sun X, Chen Y, Hu M, Hou X, Liu C. Relationships of sagittal skeletal discrepancy, natural head position, and craniocervical posture in young Chinese children. Cranio ${ }$. 2016; 34 (3): 155-162.

29. Vukićević V, Petrović Đ. Relationship between head posture and parameters of sagittal position and length of jaws. Med Pregl. 2016; 69 (9-10): 288-293. 